\title{
Ebaco-R: Refinement of organizational commitment
}

\section{bases scale}

\author{
Leandro Trigueiro-Fernandes ${ }^{1,2+}$ \\ ${ }^{1}$ Universidade Federal do Rio Grande do Norte, Natal, RN, Brazil \\ ${ }^{2}$ Universidade Potiguar, Natal, RN, RN, Brazil \\ Marcos Luiz Lins Filho ${ }^{3, \Omega(D)}$ \\ ${ }^{3}$ Instituto Federal da Bahia, Eunápolis, BA, Brazil \\ Anderson Luiz Rezende Mól 4,¥(1) \\ ${ }^{4}$ Universidade Federal do Rio Grande do Norte, Natal, RN, Brazil \\ Miguel Eduardo Moreno Añez ${ }^{5, *(D)}$ \\ ${ }^{5}$ Universidade Federal do Rio Grande do Norte, Natal, RN, Brazil
}

\section{ABSTRACT}

Despite being extensively studied, the organizational commitment still remains in the research agenda due to a lack of consensus on conceptual and structural issues. Therefore, this research proposed to refine the Organizational Commitment Bases Scale (EBACO) in search for an instrument with better psychometric properties and a better theoretical adjustment. The research was divided into two phases, the first one was eminently exploratory, carried out with 149 observations, and evaluated the EBACO's psychometric fitting with the reduction of two bases. The second phase, confirmatory, occurred in 45 organizations - 27 public and 18 private, with 812 observations. The confirmatory factor analysis was adopted to evaluate the psychometric properties and the theoretical adequacy of the refined model. The results indicated that with five dimensions the EBACO model presented higher levels of KMO, Cronbach's Alpha, and explained variance. It was also verified that the model discussed obtained adequate values of the goodness of fit indexes $\chi^{2} / \mathrm{df}$, RMSEA, CFI, TLI and RMR. Finally, it was verified that the refined model, EBACO-R, presented a convergent validity, ensuring a greater suitability of the scale to the theory. Furthermore, the model refinement, excluding the bases, contributes to the discussion by Osigweh (1989) about the 'concept stretching' commitment.

Keywords: Organizational Commitment. EBACO. Confirmatory Factor Analysis. Convergent validity. EBACO-R.

\section{INTRODUCTION}

The search for a better comprehension on the relationship between the individual and the organization has been an object of study for decades. Ever since the concept of organizational commitment became present in the organizations' daily routine, the main challenge of the area has been anchored to the comprehension of the factors which influence the individual to be more involved with the organization and, consequently, with their work (Cunha, Silva, Estivalete, Hörbe, \& Moura, 2017).

Upon studying the topic, there is an apparent breakdown between researchers of the area regarding the foundations that make the organizational commitment, and the trend that defends the existence
Corresponding author:

† Universidade Federal do Rio Grande do Norte, Brazil

Universidade Potiguar, Natal, RN, Brazil E-mail: adm@leandrotrigueiro.com

$\Omega$ Universidade Federal do Rio Grande do Norte, Natal, RN, Brazil

E-mail: marcoslins@gmail.com

${ }^{¥}$ Universidade Federal do Rio Grande

do Norte, Natal, RN, Brazil

E-mail: mol.ufrn@gmail.com

* Universidade Federal do Rio Grande

do Norte, Natal, RN, Brazil

E-mail: anez1957@yahoo.com.br

Received: 09/17/2017.

Revised: 04/30/2018.

Accepted: $07 / 30 / 2018$

Published Online: 05/15/2019

DOI: http://dx.doi.org/10.15728/bbr.2019.16.4.1 
of multiple dimensions is one of the strongest within this construct. On the other hand, there is an increase of discussion on the commitment construct dimensionality decline, from the identification of the elements which do not constitute the concept's central basis, dissociating these elements into new constructs, as for the organizational entrenchment (Osigweh, 1989; Cooper-Hakim \& Viswesvaran, 2005; Bastos, Siqueira, Medeiros, \& Menezes, 2008; Rodrigues \& Bastos, 2010; Balsan et al., 2015; Menezes, Aguiar, \& Bastos, 2016).

This study is placed under the construct multidimensionality perspective. However, it agrees with the 'concept stretching' discussion presented by Osigweh (1989), and supported by Rodrigues and Bastos (2010), which says there might be a concept overlap, due to the incorporation of elements, which cause problems of accuracy and validity, making the construct's conceptual comprehension and its bases more complex.

Within this context, the work by Meyer and Allen (1991), one of the seminals from the multidimensionality perspective, establishes the three dimensions with higher relevance on literature about the topic: affective attitude, normative and instrumental. For Medeiros (2003), the study by O'Reilly and Chatman (1986) must also be considered as another important multidimensional model for the organizational commitment. The model is founded on the theory proposed by Kelman (1958), which attributes three bases to the psychological bond: instrumental involvement (based on rewards), identification (based on affiliation) and internalization (based on individual and organizational values).

However, authors such as Meyer and Allen (1991), O'Reilly and Chatman (1986) reinforce the need to widen the studies in the area, especially when it comes to construct dimensionality. For Medeiros, Albuquerque, Marques and Siqueira (2005), in addition to the existing gap pertaining to the construct dimensionality, one must also consider the difficulty to adapt a measuring scale to the cultural reality of the organization and of the place. Anticipating this difficulty, Medeiros (2003) developed the Organizational Commitment Bases Scale (EBACO), composed of seven bases: affective, obligation to remain, obligation for performance, affiliative, lack of rewards and opportunities, consistent line of activities and shortage of alternatives.

The EBACO model, created a little over a decade ago, has been widely adopted in scientific studies of organizational commitment in Brazil for dissertations and theses (Pena, 2009; Lages, 2010; Halla, 2010; Loth, 2010; Silva, 2012; Cantarelli, 2012; Menetti, 2013; Amaro, 2013), as well as for scientific studies on administration and organizational psychology (Lopes \& Basso, 2009; Estivalete, Löbler, Visentini, \& Andrade, 2010; Kuabara \& Sachuk, 2010; Campos, Estivalete, \& Reis, 2011; Sousa \& Honório, 2011; Lemos, Cavazotte, \& Nogueira, 2012; Cantarelli, Estivalete, \& Andrade, 2014; Cunha et al.,2017; Melo, Fernandes, Araújo, Silva, \& Santos, 2014; M. A. D. S. Melo et al., 2014; Menetti, Kubo, \& Oliva, 2015).

Despite its wide use, the EBACO model by Medeiros (2003) hasn't proved its convergent validity - a statistical measure which guarantees a higher adequacy of scale to theory. Within this perspective, this research proposes to refine the EBACO in the search for a tool with better psychometric properties and greater theoretical adequacy. This shows this work's relevance and topic currentness, since several studies that deal with revising the scales to solve structural problems have been published recently (Klein, Cooper, Molloy, \& Swanson, 2014; DeBode, Armenakis, Feild, \& Walker, 2013).

The research was developed in two phases. The exploratory phase comparatively evaluated the EBACO's original model with a refined version (EBACO-R) - defined from the exclusion of two bases that presented some psychometric issues. The confirmatory phase tried to evaluate the EBACO-R's psychometric properties and the theoretical adequacy, with the convergent validity as the main property. 
BBR

16,4

Besides the introduction section, this article is divided into four more sections. In section 2 , we review the literature on organizational behavior and the model developed by Medeiros (2003). In the following section, we present the methodology adopted for conducting this study. In section 4, we analyzed and discussed the results obtained in the research. Then, in the last section, we present the conclusions and this study's limitations.

\section{LITERATURE REVIEW}

\subsection{Organizational COMMITMENT}

Due to a more and more competitive scene that the market imposes over organizations, there is a growing interest from managers to measure their collaborators' commitment, since there is a straight relationship with organizational performance. Thus, the commitment arises as a strategic element which is able to generate a competitive differential (Medeiros, 2003; Medeiros \& Albuquerque, 2005; Rodrigues \& Bastos, 2010; Klein, 2013).

In this sense, we have noticed an increase in the number of research, which deal with the organizational commitment topic in the past few decades, motivated by the work relations and by the searching efforts and retention of committed people. These aspects come from social transformations, from the technological, economic, demographical and cultural points of view (O'Reilly \& Pfeffer, 2001; Medeiros, 2003; Morrow, Mcelroy, \& Scheibe, 2012).

So, in order to meet the organizational commitment measurement demand and follow up on the transformations mentioned above, scales were created to incorporate elements into the commitment construct, making it more complex, due to possible concept overlapping. In this sense, the literature pointed out problems of model specification, consistency, accuracy and validity, oftentimes due to the lack of proper attention from some researchers or from concept widening, without using well-established theoretical criteria (Mowday, Porter, \& Steers, 1982; Osigweh, 1989; Rodrigues \& Bastos, 2010). In face of the facts, the works which were able to contribute to the scales' structural problems' review and resolution stood out (Klein et al., 2014; DeBode et al., 2013).

Based on the aspects mentioned above, it becomes more difficult to reach a consensus as to the nature and dimensionality of the bonds that exist between the individual and the organization, making it an evolving construct, with several forms of conceptualization (Cooper-Hakim \& Viswesvaran, 2005; Medeiros et al., 2005; Cohen, 2007; Menezes \& Bastos, 2009; Klein, Molloy, \& Cooper, 2009; Costa \& Bastos, 2014). Table 1 below presents other conceptualizations on the organizational commitment topic, presented by some of the main authors on the theme.

The definitions presented in Table 1 show the discussion plurality topic. However, they do not exhaust the main elements of conceptualization of the organizational behavior, especially the one that deals with the discussion on multidimensionality, which is an important point of difference in the studies.

Following the multidimensional perspective for the behavior, O'Reilly and Chatman (1986) presented a tool to operationalize the three-dimension model proposed by Kelman (1958) and validated from two studies led by these authors. As a contribution, the authors widened the discussions and reflections on organizational commitment multidimensionality and saw the relationship between commitment and organizational performance (Medeiros, 2003; Cohen, 2007; Morrow, 2011).

Going further into the studies, Meyer and Allen (1991) developed a three-dimension model for the organizational behavior theoretical bases. According to Medeiros (2003), the adoption and the development of a multidimensional view for the organizational behavior 


\begin{tabular}{|c|c|c|}
\hline YEAR & AUTHOR & DEFINITION \\
\hline 1960 & Becker & $\begin{array}{l}\text { "Commitment takes place when, through investments, a person relates other interests to a consistent line } \\
\text { of activities". }\end{array}$ \\
\hline 1979 & Mowday et al. & "The relative strength of an individual's identification with and involvement in a particular organization". \\
\hline 1982 & Wiener & $\begin{array}{l}\text { "The totality of normative pressures used for an individual to act according to the organizational objectives } \\
\text { and interests". }\end{array}$ \\
\hline 1986 & O’Reilly; Chatman & $\begin{array}{l}\text { "A person's psychological bond to an organization which reflects the degree he or she internalizes and } \\
\text { adopts the organization's characteristics or perspectives". }\end{array}$ \\
\hline 1991 & Allen; Meyer & "A psychological state which connects the individual to the organization". \\
\hline 2003 & Medeiros & $\begin{array}{l}\text { "The organizational commitment is noticed by individuals who do their best for the enterprise, who take } \\
\text { on their job as a challenge, and who strive for the enterprise's best results". }\end{array}$ \\
\hline 2009 & Meyer & $\begin{array}{l}\text { "It is an internal strength which connects the individual to an object (whether social or not) and/or a } \\
\text { course of action of relevance for this project". }\end{array}$ \\
\hline 2013 & Bastos et al. & $\begin{array}{l}\text { "A link or a bond which connects the employee to the organization and not only as an attitude or a power } \\
\text { that pressures him". }\end{array}$ \\
\hline 2014 & Klein et al. & "A psychological bond which reflects the dedication to and responsibility for a person's specific objective". \\
\hline
\end{tabular}

Source: Adapted from Pinto (2011) and Costa and Bastos (2014).

unveils a new phase from the 1990's with the work by Meyer and Allen (1991). The researchers noticed, then, that the unidimensional perspectives are actually components of a psychological bond between the individual and the organization and not only types of individual behaviors (Medeiros, 2003; Bastos et al., 2008; Morrow, 2011; Campos et al., 2011; Oliveira, 2013).

The three-dimension model by Meyer and Allen (1991) tried to summarize the concepts that had been related by other studies until then and became the most acceptable one among the researchers in the 1990's for making the research on the organizational behavior topic operational and, thus, enabling the appearance of new research based on the model's improvement and unfolding (Mathieu \& Zajac, 1990; Meyer \& Allen, 1991; Medeiros et al., 2005). The research by Morrow (2011), which analyzed 58 studies about organizational commitment, reaffirms the importance of the work by Meyer and Allen (1991) and also emphasizes the work by Mowday, Steers and Porter (1979), treating them as structurers of research, in this topic, and which have been performed since the 1980's.

Despite the support from several authors to the tridimensional model by Meyer and Allen (1991), we notice we are far from a consensus in the field of study, for, as stated by Balsan et. al (2015), there is an apparent autonomy between the affective and the normative dimensions in relation to the instrumental one, and also a possible overlap of the two first dimensions (affective and normative). Menezes et al. (2016) emphasize that such a fact was noticed in a meta-analysis performed by Meyer et al. themselves in 2002.

The argumentation presented by Balsan et. al (2015) and Menezes et al. (2016) confirm the current discussion that the organizational behavior needs to be limited to the formative elements to its essence, in a way there is some construct simplification and, consequently, it avoids the 'concept stretching' issue of organizational behavior pointed out by Osigweh (1989), without discarding the construct multidimensionality hypothesis.

Complementing these studies, Medeiros (2003) developed, in Brazil, the Organizational Commitment Bases Scale, EBACO, which is the object of this research's study. The model incorporates other bases that come from research on dimensionality, which are based on the three dimensions that are mostly explored by the literature, and tries to absorb the local social-cultural particularities (Bastos et al., 2008; Medeiros, 2003). It is important to add that one of the main motivations for the EBACO development was to validate the relationship of the commitment to the organizational performance, trying to meet "a great literature 
BBR

16,4

demand to empirically prove that the organizational commitment leads the enterprises to a better performance" (Medeiros, 2003, p.126).

\subsection{THE ORGANIZATIONAL COMMITMENT BASES SCALE}

Medeiros (2003) developed the Organizational Commitment Bases Scale - EBACO - because he saw the need for a tool that could measure the organizational behavior considering the Brazilian culture particularities and, at the same time, allowed to meet a latent demand about the scientific existence and evidence of the relationship between commitment and organizational performance.

The EBACO model conception was preceded by the work by Medeiros and Enders (1998), which validated the commitment tridimensional model (affective, normative and instrumental) by Meyer and Allen (1991), reaching a similar conclusion about the possibility of existence of other latent dimensions or organizational commitment or even subdivisions of the existing ones. This work emphasized a new dimension, which deals with the emotional bond between the individual and the organization, and which was confirmed by Medeiros, Enders, Sales, Oliveira and Monteiro (1999), calling it an Affiliative basis.

Medeiros (2003) used the four main perspectives of commitment for elaborating the EBACO: affective, normative, instrumental and affiliative. For such, he applied the model by O'Reilly and Chatman (1986) associated to the model by Meyer and Allen (1991), and proposed a summary between the theories and the theoretical models of commitment.

In this sense, he defined the EBACO model composed of 28 observable variables, equally divided into seven latent dimensions. One dimension representing the affective and the affiliative approach each, two representing the normative approach, and three representing the instrumental approach. The dimensions were highlighted after the exploratory and confirmatory factor analysis performance. The 'obligation to remain' and 'obligation for performance' bases correspond to the normative approach of organizational commitment, and the 'shortage of alternatives', 'consistent line of activities' and 'lack of rewards and opportunities' bases correspond to the instrumental approach. Table 2, below, presents the EBACO's commitment bases with their respective definitions and theoretical grounds.

In the EBACO model, conceived by Medeiros (2003) and validated by Bastos et al. (2008), the seven bases presented important indexes of internal consistency (Cronbach's Alpha), as seen in Table 3.

It is important to highlight that the observable variables measured the dimension previously established by the EBACO, as it can be seen from the Cronbach's Alpha internal consistency analysis. However, the work by Medeiros (2003) didn't determine the convergent validity between the latent dimensions of organizational commitment. In addition, such validity was not studied in any of the several works carried out previously, and which used the EBACO as a model for evaluating the organizational commitment.

Under the methodological aspect, we also noticed that the 'obligation to remain' and the 'lack of rewards and opportunities' bases presented lower levels of psychometric adjustments within their respective approach. As for the first basis, Medeiros (2003) chose to rule out one of the observable variables, which disabled this dimension's fitting evaluation. As for the second basis, in its confirmatory study, the author reports some problems in the indicators' development, which caused a low internal consistency and cross loading in one of the observable variables, whose factor loading was more relevant for the other factor.

Besides the psychometric properties related to commitment itself, the two bases mentioned above also presented limitations in the empiric study carried out by Medeiros (2003) in his Doctor's thesis, which aimed at validating the relationship between commitment and organizational performance. The 'lack of rewards and opportunities' basis didn't form the path analysis model which associated the two constructs, whereas the 'obligation 
Table 2 - EBACO'S theoretical ground bibliographical layout

\begin{tabular}{|c|c|c|}
\hline \multicolumn{2}{|c|}{ ORGANIZATIONAL COMMITMENT BASES } & THEORETICAL \\
\hline Affective & $\begin{array}{l}\text { Belief in and identification with Philosophy, with values and } \\
\text { organizational objectives. }\end{array}$ & $\begin{array}{l}\text { Mowday, Porter and Steers (1982); } \\
\text { Kelman (1958); Goudner (1960); } \\
\text { Sá and Lemoine (1998). }\end{array}$ \\
\hline Affiliative & $\begin{array}{l}\text { Belief of acknowledgment from coworkers as a member of the } \\
\text { group and the organization. }\end{array}$ & $\begin{array}{l}\text { Kelman (1958); Gouldner (1960); } \\
\text { Becker (1992); Mowday, Porter and } \\
\text { Steers (1982); Medeiros and Enders } \\
\text { (1999). }\end{array}$ \\
\hline Obligation to remain (Normative) & $\begin{array}{l}\text { Belief there is the obligation to remain, that it wouldn't be } \\
\text { right to leave; and that there is a moral obligation to the } \\
\text { organization's people. }\end{array}$ & $\begin{array}{l}\text { Meyer and Allen (1991); Jaros et al. } \\
\text { (1993). }\end{array}$ \\
\hline $\begin{array}{l}\text { Obligation for performance } \\
\text { (Normative) }\end{array}$ & $\begin{array}{l}\text { Belief that they must work hard for the organization's benefit } \\
\text { and that they must reach the organizational objectives. }\end{array}$ & $\begin{array}{l}\text { Wiener (1982) and Jaros et al. } \\
\text { (1993); Mowday, Porter and Steers } \\
\text { (1982). }\end{array}$ \\
\hline $\begin{array}{l}\text { Lack of rewards and opportunities } \\
\text { (Instrumental) }\end{array}$ & $\begin{array}{l}\text { Belief that the steps taken to benefit the organization must } \\
\text { be better rewarded, and that the organization must give them } \\
\text { more opportunities. }\end{array}$ & $\begin{array}{l}\text { Mowday, Porter and Steers (1982); } \\
\text { Sá and Lemoine, 1998); Becker } \\
\text { (1992). }\end{array}$ \\
\hline $\begin{array}{l}\text { Consistent line of activities } \\
\text { (Instrumental) }\end{array}$ & $\begin{array}{l}\text { Belief that they must attain to certain organizational behaviors } \\
\text { and rules aiming at remaining in the company. }\end{array}$ & $\begin{array}{l}\text { Becker (1960); Hrebiniak and } \\
\text { Alutto (1972); McGee e Ford } \\
\text { (1987). }\end{array}$ \\
\hline $\begin{array}{l}\text { Shortage of alternatives } \\
\text { (Instrumental) }\end{array}$ & $\begin{array}{l}\text { Belief that there are a few alternatives for work out of the } \\
\text { organization. }\end{array}$ & $\begin{array}{l}\text { Meyer and Allen (1991), McGee } \\
\text { and Ford (1987). }\end{array}$ \\
\hline \multicolumn{3}{|c|}{ Source: Adapted from Bastos et al. (2008, p. 62). } \\
\hline \\
\hline \multicolumn{2}{|c|}{ BASES AND THEIR RESPECTIVE WEIGHTS } & bach's Alpha \\
\hline \multicolumn{2}{|c|}{ Affective } & 0.84 \\
\hline \multicolumn{2}{|c|}{ Obligation to remain (Normative) } & 0.87 \\
\hline \multicolumn{2}{|c|}{ Obligation for performance (Normative) } & 0.77 \\
\hline \multicolumn{2}{|c|}{ Affiliative } & 0.80 \\
\hline \multicolumn{2}{|c|}{ Lack of rewards and opportunities (Instrumental) } & 0.59 \\
\hline \multicolumn{2}{|c|}{ Consistent line of activities (Instrumental) } & 0.65 \\
\hline \multicolumn{2}{|c|}{ Shortage of alternatives (Instrumental) } & 0.73 \\
\hline
\end{tabular}

Source: Bastos et al., 2008, p. 64.

for performance' basis presented the most distant relationship with the organizational performance variable.

From the theoretical point of view, the discussions around the need of a model simplification and, consequently, around the measurement scales, are relevant, so that the organizational commitment limits to the constituent elements of its essence more and more (Rodrigues \& Bastos, 2010; Balsan et al., 2015; Menezes et al., 2016). However, it is important that we do not lose the idea of construct multidimensionality, since it comprises the EBACO's conception basis.

Considering the aspects presented previously, McGee and Ford (1987) marked that the 'continuation' dimension (instrumental approach) would be comprised only by the 'high personal sacrifice' basis (associated to the EBACO's 'consistent line of activities' basis) and by the 'few alternatives perceived' basis (associated to the EBACO's 'shortage of alternatives' basis). From this perspective, the 'lack of rewards and opportunities' basis became prone to being ruled out of this study for the EBACO model refinement. In the same sense, the 'obligation for performance' basis (normative approach) presents an overlap with the affective approach, as pointed out in studies by Meyer et al. (2002). In addition, the basis doesn't comprise the sub-construct of obedience or organizational consent specified by Silva (2009) nor the normative dimension sorted out by Bastos et al. (2008), becoming 
BBR

16,4

prone to being one more item to be ruled out of this study. This discussion is also subsidized by the authors Meyer and Allen (1991), Cooper-Hakim and Viswesvaran (2005) and Klein et al. (2011) who don't handle these bases as components of the normative and instrumental approaches.

Thus, the study went on with the proposition of a refined EBACO version, named EBACO-R, defined from the exclusion of the 'lack of rewards and opportunities' and 'obligation for performance' bases. This refined version tried to reach a better theoretical adequacy both for the aspect of convergent validity and for the delimitation of what comprises the organizational commitment concept essence.

\section{RESEARCH METHODOLOGY}

The present research is characterized as a field study and aimed at refining the Organizational Commitment Bases Scale (EBACO) in the search for a tool with better psychometric properties and better theoretical adequacy. For such, it was divided into two phases, with the first one being eminently exploratory and the second one with a confirmatory character.

In the exploratory research, the study was carried out based on 149 observations in two organizations, one public and one private. In this phase, the main objective was to check if the scale's refined version psychometric properties (EBACO-R) presented any statistic adequacy in comparison to the original EBACO model that could subsidize the decision for research continuation. It is worth highlighting that the scale's refined version was based on the findings of psychometric issues of the scale itself and on the theoretical propositions which point out to the commitment bases review, both in the scale's structural and conceptual aspects (Rodrigues \& Bastos, 2010; Mowday et al., 1982).

The data collection process was performed through interviewers who participated onsite in the organizations. The sample composition used in the two phases of the research was conducted based on a convenience sampling since it deals with a field research where the interviewers would visit the organizations and directly question the employees about who was present at that moment, so that they could answer the research questionnaire. From the 149 interviewees in the first step, $57.05 \%$ belonged to an organization from the public sector, and $42.95 \%$ to the private sector. It is important to emphasize that the tool used in the research was properly adjusted to a more generic profile, so that it could be applied in public and private organizations.

The tool used in this research's phase was made out of 28 closed-ended questions which measure the EBACO's seven organizational commitment bases. The questions are 6-point Likert scale type, with determined ends as totally disagree and totally agree. In the data analysis step, we used the IBM SPSS22 software. We performed two exploratory factor analyses, EFA, one with the 28 observable variables, and another with 20 , removing the 8 variables related to the two bases that were ruled out. Both EFAs were extracted through principal component analysis and the Direct Oblimin rotation with Kaiser normalization.

For the EFA results comparison with 7 and 5 factors, we used three indexes: i) the KMO (Kaiser-Meyer-Olkin), which evaluates the partial correlations' magnitude between the variables, that is, a homogeneity measure of the variables (Marôco, 2011), ii) the Cronbach's Alpha, which checks the internal consistency in each factor and in each tool as a whole (Marôco \& Garcia-Marques, 2006), and iii) the total explained variance, which checks how much from the model can be explained (Marôco, 2011; Figueiredo \& Silva, 2009; Hair et al., 2006).

In the second phase, which started based on the indicative that the refined version (EBACO-R) presented a satisfactory statistic quality in order to advance into the study, we adopted the confirmatory factor analysis to evaluate the EBACO-R's psychometric 
properties and the theoretical adequacy, with the convergent validity as the main property, since this makes the scale more consistent, for it assures the existence of a meaningful correlation between the bases and their respective observable variables (Pasquali, 1997; Marôco, 2010). In this phase, we checked on 45 organizations, 27 from the public sector and 18 from the private sector, totaling 812 valid observations. From the interviewees in this research's phase, $47.10 \%$ belonged to organizations in the public sector and $52.90 \%$ belonged to the private sector.

Before proceeding to the Confirmatory Factor Analysis, CFA, the second phase in the research, we checked whether the requirements to guarantee the reasonability of the model proposed were met, which was also a step in the data processing. From the main requirements, we should mention that the evidence suggest a multivariate normality checked with the use of the skewness (sk) and the kurtosis (k) measures, which maintained with the tolerance limits mentioned by Kline (2004). Through the Mahalanobis distance, we identified 78 outliers, which were ruled out of the sample. By estimate, there were no void associations between the observable variables and their respective latent factors, neither values higher than 1 nor lower than -1 in the estimated standardized coefficients, which would indicate multicollinearity (Marôco, 2010).

In this phase, the tool was made out of 20 closed-ended questions, which measure the 5 latent factors in the study. As in the exploratory phase, we used the 6-point Likert scale for the questions. For the CFA fulfillment and identification of their goodness of fit indexes, we used the IBM SPSS 22 and the Stata/SE12 software programs. The estimate method used was that of Maximum Likelihood, since it is the most robust in the presence of multivariate normality and of a sample with a large number of observations.

At first, we performed a CFA for each latent dimension and its respective observable variables, with the objective to evaluate the indicators' adequacy in every organizational commitment basis. In order to evaluate the adjustment, we adopted the CFI, Comparative Fit Index, which must be higher than 0.90, and the SRMR, Standardized Root Mean Square Residual, which must be lower than 0.10 (Worthington \& Whittaker, 2006). For the internal consistency analysis in each factor, we calculated the Cronbach's Alpha, adopting 0.7 as a critical value (Marôco \& Garcia-Marques, 2006; Hair et al., 2006).

Subsequently, we performed the CFA including all the five model dimensions so that we could evaluate the global adjustment, as well as its convergent and composite validity. The goodness of fit indexes adopted in this research's confirmatory step are expressed in Table 4 , with their respective reference values, and represent the fitting evaluation categories pointed out by Marôco (2010) and Ullman (2007).

In order to check the need for model re-specification, we observed the Modification Indexes (MI), which must be higher than 11 so that the fit performance may be justified (Marôco, 2010). In addition, as the modifications must be done in case there is a theoretical back up, this research adopted as a pattern the establishment of covariance relationships only between the mistakes in the observable variables in the same latent dimension. In this sense, it is reasonable to admit that they may share mutual information that was not prone to be observed.

The convergent validity, the main psychometric property discussed in this research, and which was not met in the EBACO model developed by Medeiros (2003), was evaluated under two perspectives. The first one, following the indication by Marôco (2010), in which we calculated the Average Variance Extracted (AVE), whose value must be higher than or equal to 0.5. The second one, embracing the suggestion by Pasquali (1997) that the latent variables must significantly correlate with themselves, since the theory accepts the existence of such relationship. Complementarily, we performed an analysis on the composite validity that estimates the observable variables' degree of consistency with their 
BBR

16,4

Table 4 - Goodness of fit indexes adopted in the confirmatory research Goodness of fit Index

$\chi^{2} / \mathrm{df}$

RMSEA

CFI

TLI

RMR

AIC

BIC

Source: Adapted from Marôco, 2010.

respective constructs, being typified as appropriate when the value is higher than or equal to 0.7 (Marôco, 2010).

\section{RESULTS ANALYSIS AND DISCUSSION}

\subsection{A PRELIMINARY STUDY FOR THE EBACO'S REFINEMENT}

As we evaluate the EBACO model created by Medeiros (2003), composed of 7 commitment bases, we noticed that two of these bases, 'obligation for performance' and 'lack of rewards and opportunities', presented limitations as for the psychometric adjustments. As for the first basis, Medeiros (2003) chose to rule out one of the observable variables, which disabled the fitting evaluation within this dimension. As for the second basis, the author reports the issue on the indicators' construction in his study, which caused a low internal consistency and cross loading in one of the observable variables, whose factor loading was more relevant for the other factor.

To this diagnosis we should add the behavior limitation of the two bases in the study in which Medeiros (2003) validated the relationship between commitment and organizational performance. Such relationship consists of one of the main discussions for the original EBACO's scale construction. As the 'obligation for performance' basis presented a longer distance in the path analysis in relation to the performance construct, the 'lack of rewards and opportunities' basis didn't present any relevant statistical indexes to comprise the association model previously mentioned.

To the theoretical discussion on the commitment's construct composition, we should add the methodological and psychometric aspects previously discussed. As we analyze McGee and Ford (1987), we notice that the 'lack of rewards and opportunities' basis doesn't comprise the instrumental approach concept, just like the 'obligation for performance' basis is not present in the sub-construct of obedience or organizational commitment specified by Silva (2009) nor in the normative dimension discussed by Bastos et al. (2008). This discussion is also supported by Meyer and Allen (1991), Cooper-Hakim and Viswesvaran (2005), Rodrigues and Bastos (2010) and Klein, Molloy and Cooper (2011), who don't deal with these bases as components of the instrumental and normative approaches, respectively.

Based on the considerations above due to a) lack of information on the goodness of fit indexes and low internal consistency, b) the lack of variables' adoption to the theoretical model of commitment association with the organizational performance, which makes the EBACO's discussion basis, and c) the theoretical indications that the two variables do not directly form the commitment construct, the exclusion of these two bases didn't signal the path taken by this study for revising the model proposed by Medeiros (2003). It is appropriate to add that, besides what was previously exposed in the EBACO's original model validation by Bastos et al. (2008), the two bases indicated also presented lower precision indexes 
within their respective commitment approaches: normative and instrumental, which is, therefore, one more argument to reinforce the scale's refinement to 5 bases.

The arguments presented encouraged the realization of this research's first phase, which tried to statistically check the exclusion effects of the two bases. For such, we chose to carry out an EFA, having the comparison between the fit quality indexes obtained as ground for the EBACO model with 7 and 5 factors. Table 5 presents the results of these indexes.

It is important to add that in the two compositions investigated, with 7 and with 5 factors, we realized that, according to the EFA, all the indicators measured the construct previously established as described in the EBACO. No indicator measures any other dimension besides its own, considering its heavier factor loading.

Based on the results in Table 5, we also notice that the two models presented adequate indexes according to the methodological recommendations (Hair et al., 2006; Marôco, 2010). However, it is important to mention that with 5 factors the model presented some slightly better indexes for the total variance explained (67.39\%), KMO (0.788), and Cronbach's Alpha (0.85), supporting the initial proposition of ruling out the 'obligation for performance' and the 'lack of rewards and opportunities' bases, allowing this research to go further into the second phase.

\subsection{EBACO'S CONFIRMATORY FACTOR ANALYSIS WITH 5 BASES}

In the second phase of this research, we initially carried out a CFA for each latent dimension and its respective observable variables, with the objective to evaluate the indicators' adequacy in each organizational commitment basis. Then, also through the CFA, the proposed model with 5 bases was tested as to its convergent and composite validity, since, in order for the model to be considered valid, the existence of relationships between the latent dimensions is indispensable, as expected from theory.

Before methodologically discussing the EBACO's new configuration, it is necessary to mention that this research supported the hypothesis of the organizational commitment multidimensionality, confirming the studies by O'Reilly and Chatman (1986); Mathieu and Zajac (1990); Meyer and Allen (1991); Bastos et al. (1997); Medeiros et al. (2005); Cooper-Hakim and Viswesvaran (2005), Cohen (2007), among others. Likewise, the

Table 5 - Self-value, Variances, KMO and Alpha from EFA with 7 and 5 Factors

\begin{tabular}{|c|c|c|c|c|c|}
\hline \multirow[b]{2}{*}{ COMMITMENT BASES } & \multicolumn{5}{|c|}{7 Factors } \\
\hline & Self-value & $\begin{array}{l}\text { Explained } \\
\text { Variance\% }\end{array}$ & $\begin{array}{c}\text { Total } \\
\text { Variance\% }\end{array}$ & $\mathrm{KMO}$ & Alpha \\
\hline Affective & 1.41 & 5.05 & & & \\
\hline Obligation to Remain & 1.91 & 6.84 & & & \\
\hline Obligation for performance & 2.75 & 9.80 & & & \\
\hline Affiliative & 6.37 & 22.74 & 66.58 & 0.771 & 0.825 \\
\hline Consistent Line of Activities & 1.20 & 4.29 & & & \\
\hline Shortage of Alternatives & 3.89 & 13.88 & & & \\
\hline Lack of rewards and opportunities & 1.11 & 3.98 & & & \\
\hline \multirow[b]{2}{*}{ COMMITMENT BASES } & \multicolumn{5}{|c|}{5 Factors } \\
\hline & Self-value & $\begin{array}{c}\text { Explained } \\
\text { Variance\% }\end{array}$ & Total Variance $\%$ & $\mathrm{KMO}$ & Alpha \\
\hline Affective & 1.38 & 6.91 & & & \\
\hline Obligation to Remain & 2.03 & 10.14 & & & \\
\hline Affiliative & 5.91 & 29.53 & 67.39 & 0.788 & 0.852 \\
\hline Consistent Line of Activities & 1.20 & 6.02 & & & \\
\hline Shortage of Alternatives & 2.96 & 14.79 & & & \\
\hline
\end{tabular}


BBR

16,4

discussions on concept simplification and, consequently on the organizational commitment measurement scales, have become more and more relevant in the light of the notorious 'concept stretching' criticized by Osigweh (1989), Rodrigues and Bastos (2010), Balsan et al. (2015) and Menezes, Aguiar and Bastos (2016). Therefore, this research also supports this discussion upon suggesting the EBACO's simplification through the exclusion of these two variables.

The fitting evaluation measures we adopted in the confirmatory analysis between the latent dimensions and their respective indicators were the CFI and the SRMR indexes. For the internal consistency analysis of each factor (latent dimension), we calculated the Cronbach's Alpha and also checked if the internal consistency would improve with the exclusion of some indicators. These indexes, as well as the measurement model with the standardized loadings, can be seen in Table 6 .

We noticed that all the observable variables' factor loadings presented high significance levels, p-value 0.001 , in relation to its construct. In addition, the goodness of fit indexes (CFI and SRMR) and the Cronbach's Alpha meet the reference parameters specified by Marôco (2010), Hair et al. (2006) and Worthington and Whittaker (2006). The CFIs were higher than 0.90, the SRMRs were lower than 0.10 and the Alphas were higher than 0.7, except the 'Consistent line of activities' dimension, whose Alpha reached the reliability level accepted only when the 'line02' variable was excluded. In this sense, in order to keep an acceptable reliability of this construct, we chose to exclude the variable.

The significance results of the model loadings in the goodness of fit indexes' measurement model, and in the internal consistency obtained through the CFA, performed individually for each construct, allow us to state that the indicators can be explained by the latent dimension that is related.

The model adjusted by this research is comprised of five out of the seven latent dimensions of the organizational commitment, highlighted by Medeiros (2003): affective, obligation to remain, affiliative, shortage of alternatives and consistent line of activities, and their respective observable variables.

The model fitting process was performed based on the MI obtained after the model's initial estimate. As previously reported, we only analyzed the variables' mistake covariance relationship indicators which make the same latent dimension. Table 7 presents the adjustments established as suggested by the MI. It is worth noting that for every fitting performed, the model was re-estimated in order to check its convergence and obtain new indicators of modification, which could improve the model adjustment.

All the standardized factor loading values, in both models with and without fit, presented some significance from the correlation point of view between the latent and observable variables. The correlations between the latent dimensions in both models were also significant, previously indicating the possibility of a model convergent validity, based on criterion established by Pasquali (1997). Figure 1 presents the models with and without fit.

The indexes' results which evaluated the model's fitting quality are shown in Table 8 .

As a result of the model adjustment, we noticed that most of the indexes reported values that were considered as very good by the literature (Ullman, 2007; Marôco, 2010). Out of the indexes which evaluate the models' adequate quality, there was a significant decrease in the $X^{2} / d f$ value to 2.93 , bringing closer the reference value model that considers the fit as good. The RMR index presented a value of 0.09 , showing a low representativeness of mistakes and, consequently, a better fit for the model.

As for the CFI and the TLI indexes, both presented values of 0.97 , showing a very good fit (Marôco, 2010). In the indexes category of population discrepancy, the RMSEA reached a value of 0.049 , showing that the model has a very good fit of the averages and the variances when compared to the population model. 
Table 6 - Latent dimensions and goodness of fit indexes, and the organizational commitment bases' consistency

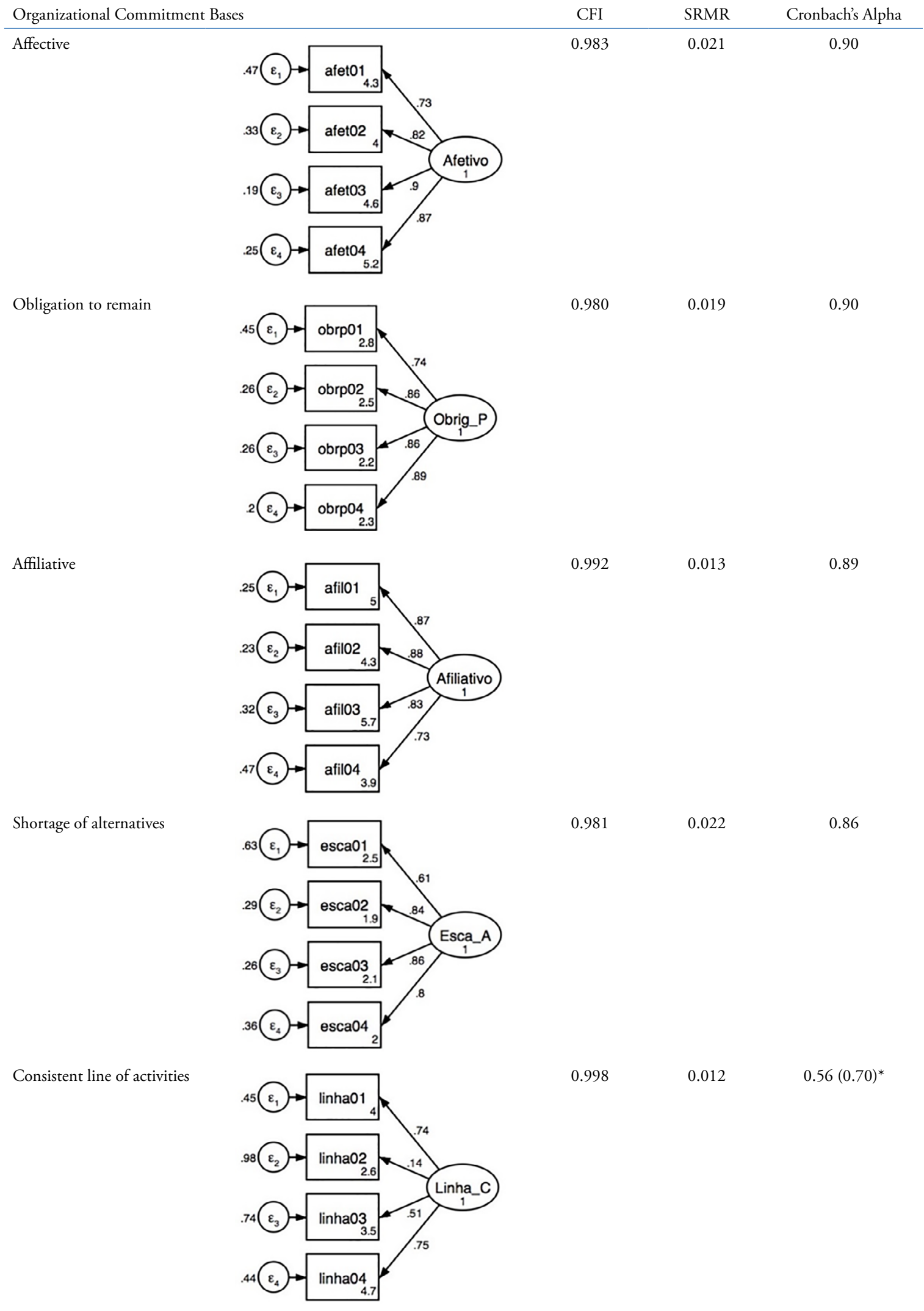

Obligation to remain
Shortage of alternatives

Source: Research data, 2016

*In brackets, the Cronbach's Alpha with the exclusion of the line 02 variable. 
BBR

16,4

327

Table 7 - Fitting sequence performed from the MI

\begin{tabular}{ccc}
\hline Sequence & Covariance relationship & MI \\
\hline 1 & $\varepsilon 15 \leftrightarrow \varepsilon 16$ & 65.37 \\
2 & $\varepsilon 3 \leftrightarrow \varepsilon 4$ & 60.47 \\
3 & $\varepsilon 5 \leftrightarrow \varepsilon 7$ & 41.67 \\
4 & $\varepsilon 10 \leftrightarrow \varepsilon 12$ & 23.54 \\
5 & $\varepsilon 9 \leftrightarrow \varepsilon 12$ & 21.08 \\
6 & $\varepsilon 10 \leftrightarrow \varepsilon 11$ & 34.67 \\
7 & $\varepsilon 18 \leftrightarrow \varepsilon 19$ & 13.99 \\
\hline
\end{tabular}

Source: Research data, 2016.

Figure 1 - EBACO’s Confirmatory Factor Analysis with 5 latent dimensions

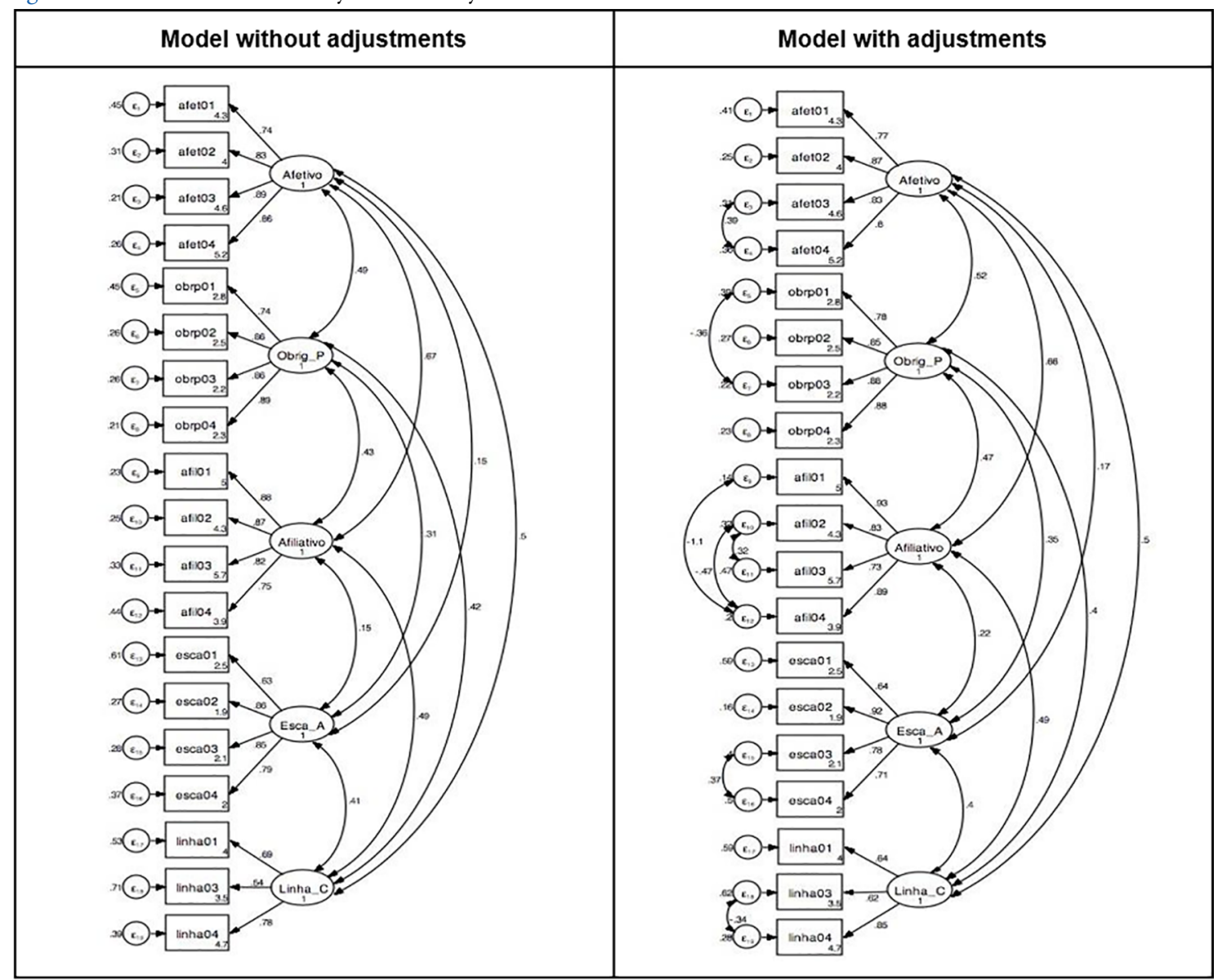

Source: Research data, 2016.

Table 8 - Model Goodness of fit Indexes

\begin{tabular}{lccc}
\hline $\begin{array}{l}\text { Goodness of fit } \\
\text { Index }\end{array}$ & Reference Value (Marôco, 2010) & Model without adjustments & Model with adjustments \\
\hline$\chi^{2} / \mathrm{df}$ & $<2$ (good) / ]2;5] (acceptable) & 4.66 & 2.93 \\
RMSEA & $\leq 0.08$ & 0.067 & 0.049 \\
CFI & $\geq 0.90$ & 0.94 & 0.97 \\
TLI & $\geq 0.90$ & 0.93 & 0.97 \\
RMR & better $<$ (nearly zero) & 0.13 & 0.09 \\
AIC & better $<$ & 845.91 & 504.96 \\
BIC & better $<$ & 1080.89 & 763.43 \\
\hline
\end{tabular}

Source: Research data, 2016. 
Lastly, we used the AIC and the BIC indexes to support the decision in relation to the preference between the models: without fit and with fit. The values obtained by these indexes pointed to the fitted model as the best choice.

\subsubsection{THE EBACO'S MODEL CONVERGENT VALIDITY TEST WITH 5 BASES}

The convergent validity is an important property that needs to be checked in a scale's construction or adjustment, since it is responsible to highlight the consistency of factors and the existence of a significant correlation between the bases and their respective observable variables, that is, it shows the scale's adequacy to theory (Pasquali, 1997; Marôco, 2010).

According to Pasquali (1997), in order for the convergent validity to be checked, the variables need to present a significant correlation to themselves. Marôco (2010) pinpoints another way to perform this check. For him, in case the levels of AVE (Average Variance Extracted) from the latent factors and from the complete model are higher than 0.5 , it is possible to confirm the existence of a convergent validity.

The fitted model, presented in the previous topic and which was selected after the AIC and the BIC goodness of fit indexes results, met the fit requirements discussed by Pasquali (1997) and by Marôco (2010). Table 9 presents the correlation matrix between the organizational commitment latent dimensions, in which it is possible to see that, despite the different magnitudes, all the correlations are significant at the $1 \%$ level.

Following the classification by Cohen (1998), used by Figueiredo and Silva (2009), it is possible to describe the correlations' magnitude. The following presented correlations of low magnitude: 'shortage of alternatives $<->$ affective' and 'shortage of alternatives $<$ $>$ affiliative'. With mean magnitude, we have: 'shortage of alternatives $<->$ obligation to remain', 'consistent line of activities<->obligation to remain', 'consistent line of activities $<->$ shortage of alternatives', 'affiliative $<->$ obligation to remain' and 'consistent line of activities $<->$ affiliative'. The remaining presented correlations of high magnitude: 'obligation to remain<->affective', 'affiliative $<->$ affective' and 'consistent line of activities $<->$ affective'. We should mention that, despite the magnitude being classified as small, mean or high, all the correlations are significant.

In Table 10, it is possible to see that all the AVE values were higher than 0.5, which meets the requirement by Marôco (2010) to check the convergent validity of each factor and of the entire model. Complementarily, we noticed that the fitted model also presented a composite validity, $\mathrm{FC}>0.7$, ratifying the variables' consistency with their respective factor.

From the findings, it is possible to state that the EBACO's refined version with 5 dimensions is valid, since it consistently measures the designed construct and has a convergent validity, for it presented some significance in the relationships between its dimensions, according to the criteria defined by Pasquali (1997) and by Marôco (2010). Besides presenting more solidity in the psychometric properties, the refined model meets the current discussions on

\begin{tabular}{|c|c|c|c|c|c|}
\hline Latent Dimensions & Affective & $\begin{array}{l}\text { Obligation } \\
\text { to Remain }\end{array}$ & Affiliative & $\begin{array}{l}\text { Shortage of } \\
\text { Alternatives }\end{array}$ & $\begin{array}{l}\text { Consistent Line } \\
\text { of Activities }\end{array}$ \\
\hline Affective & - & & & & \\
\hline Obligation to Remain & $0.52 * * *$ & - & & & \\
\hline Affiliative & $0.66 * * *$ & $0.47 * * *$ & - & & \\
\hline $\begin{array}{l}\text { Shortage of } \\
\text { Alternatives }\end{array}$ & $0.17 * * *$ & $0.35^{* * *}$ & $0.22 * * *$ & - & \\
\hline $\begin{array}{l}\text { Consistent Line } \\
\text { of Activities }\end{array}$ & $0.50 * * *$ & $0.40 * * *$ & $0.49 * * *$ & $0.40 * * *$ & - \\
\hline
\end{tabular}


BBR

16,4
Table 10 - Convergent Validity and Composite Validity Indexes

\begin{tabular}{lcc}
\hline Latent Dimensions & FC $(\geq 0.7)$ & AVE $(\geq 0.5)$ \\
\hline Affective & 0.94 & 0.78 \\
Obligation to remain & 0.95 & 0.83 \\
Affiliative & 0.95 & 0.82 \\
Shortage of Alternatives & 0.91 & 0.71 \\
Consistent Line of Activities & 0.83 & 0.63 \\
EBACO Model (5 factors) & 0.98 & 0.76 \\
\hline
\end{tabular}

Source: Research data, 2016.

the need to simplify the concept, which defends a delimitation on that which is the essence of the organizational commitment concept.

Aiming at distinguishing the original model by Medeiros (2003), which has 7 bases, we will adopt the classification of Refinement of Organizational Commitment Bases Scale, or simply EBACO-R, for the new scale configuration with 5 bases.

\section{CONCLUSIONS}

This research's main objective was to refine the Organizational Commitment Bases Scale (EBACO) in the search for an instrument with better psychometric properties and theoretical adequacy. As a result of this refinement process, the EBACO-R was set with 5 bases: affective, obligation to remain, affiliative, shortage of alternatives and consistent line of activities.

The results obtained in the exploratory phase showed that, with the five bases mentioned above, the model presented a better consistency, homogeneity and a higher level of explanation, indicating a preliminary feasibility for using the EBACO in a refined version from the statistical results and theoretical aspects, which refer to model adjustments and organizational commitment scales present in the scientific literature on the theme.

In the confirmatory phase, we realized that the refined version has a good quality, since the model presented levels of fit that are considered relevant according to literature, backing up the model's precision checked through the composite validity.

One of this research's relevant contributions refers to the EBACO-R's convergent validity confirmation. In its original version elaborated by Medeiros (2003), even if it is widely used in the commitment studies in the Brazilian context, the scale didn't have its convergent validity confirmed. In the new configuration, in addition to presenting better psychometric properties, the scale aligns with the studies that propose the simplification of models and of commitment scales upon trying to bring the concept closer together much more than its essence.

In this sense, this research also takes a step forward upon approaching the discussion on bases' structure which makes the scale, making it different from several other studies which aim at applying the EBACO as a commitment measurement tool.

We, then, come to the conclusion that the EBACO-R reached a good level of quality and accuracy to measure the organizational commitment, presenting an advantage over the original model by Medeiros (2003), since it was possible to confirm the convergent validity.

Given the new model setting elaborated by Medeiros (2003), it is essential that other works check the EBACO-R's convergent validity in different cultures and sectors of the economy. At the same time, it is important that new studies perform a path analysis between the five latent dimensions, to check possible casual relationships among themselves. It is also worth mentioning that in future studies the capacity of relationship of these five bases with backgrounds and consequences of the commitment should be checked.

As limitations of this research, we pinpoint that the 'consistent line of activities' basis was made of only three observable variables, the minimum accepted in order to reach the 
assumption of multiple indicators. It is worth noting that, in other studies, a new indicator which contributes with the accuracy of this basis' measurement should be formatted. One other limitation can be characterized due to the absence of a multi-group analysis which could confirm a homogeneous behavior of the EBACO-R scale, aside from any distinct profiles between the groups.

\section{REFERENCES}

Allen, N. J., \& Meyer, J. P. (1990). The measurement and antecedents of affective, continuance and normative commitment to the organization. Journal of Occupational Psychology, 63(1), 1-18.

Amaro, B. E. M. (2013). A geração Xe Y e as diferentes bases de comprometimento organizacional (Tese de doutorado). Pontifícia Universidade Católica do Rio de Janeiro, Rio de Janeiro, RJ, Brazil.

Balsan, L. A. G., Bastos, A. V. B., Fossá, M. I. T., Lima, M. P., Lopes, L. F. D., \& Costa, V. M. F. (2015). Comprometimento e entrincheiramento organizacional: Explorando as relações entre os construtos. Revista de Administração da UFSM, 8(2), 235-248.

Bastos, A. V. B., Brandão, M. G., \& Pinho, A. P. M. (1997). Comprometimento organizacional: Uma análise do conceito expresso por servidores universitários no cotidiano de trabalho. Revista de Administração Contemporânea, 1(2), 97-120.

Bastos, A. V. B., Rodrigues, A. C. A., Moscon, D. C. B., Silva, E. E. C., \& Pinho, A. P. M. (2013). Comprometimento no trabalho: Fundamentos para a gestão de pessoas. In Borges, L. O. \& Mourão, L. (Eds.), O trabalho e as organizações: Atuações a partir da psicologia. São Paulo: Artmed.

Bastos, A. V. B., Siqueira, M. M. M., Medeiros, C. A. F., \& Menezes, I. G. (2008). Comprometimento organizacional. In Siqueira, M. M. M. (Ed.), Medidas do comportamento organizacional: Ferramentas de diagnóstico e de gestão (pp. 49-95). Porto Alegre: Artmed.

Becker, H. S. (1960). Notes on the concept of commitment. American journal of Sociology, 66(1), 32-40.

Becker, T. E. (1992). Foci and bases of commitment: are they distinctions worth making?. Academy of Management Journal, 35(1), 232-244.

Campos, S. A. P., Estivalete, V. D. F. B., \& Reis, E. (2011). Percepções de suporte e comprometimento: Investigando a relação entre os construtos. Revista Eletrônica de Gestão Organizacional, 9(3), 534-564.

Cantarelli, N. M. (2012). Carreira e comprometimento organizacional: Ampliando a sua compreensão (Dissertação de mestrado). Universidade Federal de Santa Maria - UFSM, Santa Maria, RS, Brazil.

Cantarelli, N. M., Estivalete, V. F. B., \& Andrade, T. (2014). Âncoras de carreira e comprometimento organizacional: Ampliando a sua compreensão. Revista Base (Administração e Contabilidade) da UNISINOS, 11(2), 153-166.

Cohen, A. (2007). Commitment before and after: An evaluation and reconceptualization of organizational commitment. Human Resource Management Review, 17(3), 336-354.

Cohen, J., (1988). Statistical Power Analysis for the Behavioural Sciences. Hillsdale: Routledge.

Cooper-Hakim, A., \& Viswesvaran, C. (2005). The construct of work commitment: Testing an integrative framework. Psychological Bulletin, 131(2), 241-259.

Costa, F. M., \& Bastos, A. V. B. (2014). Comprometimento organizacional: Bases para uma abordagem processual. Psicologia: Teoria e Pesquisa, 30(3), 329-337.

Cunha, D. E., Silva, A. H., Estivalete, V. D. F. B., Hörbe, T. D. A. N., \& de Moura, G. L. (2017). Confiança do empregado na organização e comprometimento organizacional: Em busca da relação entre os construtos. Sistemas \& Gestão, 12(1), 25-37.

DeBode, J. D., Armenakis, A. A., Feild, H. S., \& Walker, A. G. (2013). Assessing ethical organizational culture: Refinement of a scale. The Journal of Applied Behavioral Science, 49(4), 460-484.

Estivalete, V. D. F. B., Löbler, M. L., Visentini, M. S., \& Andrade, T. A. I. S. (2010). Valores relativos ao trabalho e a relação com o comprometimento organizacional: A percepção dos colaboradores de uma empresa internacionalizada. Revista Base (Administração e Contabilidade) da UNISINOS, 7(2), 135-148.

Figueiredo, D. B., Filho, \& Silva, J. A. D., Jr. (2009). Desvendando os mistérios do coeficiente de correlação de Pearson (r). Revista Política Hoje, 18(1), 115-146.

Gouldner, H. P. (1960). Dimensions of organizational commitment. Administrative Science Quarterly, 4, 468-490.

Hair, J. F., Black, W. C., Babin, B. J., Anderson, R. E., \& Tatham, R. L. (2006). Análise multivariada de dados. Porto Alegre: Bookman. 
BBR

16,4

Halla, A. L. P. (2010). Quais as bases do comprometimento dos indivíduos da geração Y em uma empresa do setor privado no Brasil? (Dissertação de Mestrado), Pontifícia Universidade Católica do Rio de Janeiro, Rio de Janeiro, RJ, Brazil.

Hrebiniak, L. G., \& Alutto, J. A. (1972). Personal and role-related factors in the development of organizational commitment. Administrative Science Quarterly, 17, 555-573.

Jaros, S. J., Jermier, J. M., Koehler, J. W., \& Sincich, T. (1993). Effects of continuance, affective, and moral commitment on the withdrawal process: An evaluation of eight structural equation models. Academy of Management Journal, 36(5), 951-995.

Kelman, H. C. (1958). Compliance, identification, and internalization: Three processes of attitude change. Journal of Conflict Resolution, 2(1), 51-60.

Klein, H. J. (2013). Advances in workplace commitments: Introduction to the special issue. Human Resource Management Review, 2(23), 127-130.

Klein, H. J., Cooper, J. T., Molloy, J. C., \& Swanson, J. A. (2014). The assessment of commitment: Advantages of a unidimensional, target-free approach. Journal of Applied Psychology, 99(2), 222-238.

Klein, H. J., Molloy, J. C., \& Cooper, J. T. (2009). Conceptual foundations: Construct definitions and theoretical representations of workplace commitments. Commitment in Organizations: Accumulated Wisdom and New Directions, 1, 3-36.

Klein, H. J., Molloy, J. C., Cooper, J. T., \& Swanson, J. A. (2011). Validation of a uni-dimensional, target-free self-report measure of commitment. Annual Meeting of the Academy of Management, San Antonio, Texas, United States.

Kline, R. B. (2004). Principles and practice of structural equation modeling. New York: The Guildford Press.

Kuabara, P. S. S., \& Sachuk, M. I. (2010). Estudo do comprometimento organizacional na PEM-Penitenciária Estadual de Maringá. Qualitas Revista Eletrônica, 9(3), 1-16.

Lages, I. P. (2010). Comprometimento e cultura organizacionais: Estudo de caso em uma prestadora de serviços na área de análises de materiais e fluidos isolantes (Dissertação de Mestrado). Faculdades Integradas Pedro Leopoldo, Pedro Leopoldo, MG, Brazil.

Lemos, A. H. D. C., Cavazotte, F. D. S. C. N., \& Nogueira, A. S. (2012). Gerações produtivas e comprometimento organizacional: Um estudo comparativo com oficiais da aeronáutica. Gestão \& Planejamento-G\&P, 13(3), 694-711.

Lopes, F. C., \& Basso, E., Jr. (2009). Comprometimento organizacional: Um experimento de campo com os colaboradores na planta de Esteio de uma empresa do ramo alimentício. Opinio - Revista de Ciências Empresariais, Políticas e Sociais, 23, 42-61.

Loth, A. F. (2010). Avaliação do comprometimento dos trabalhadores da companhia Águas de Joinville com a política de saneamento básico (Dissertação de mestrado). Universidade do Vale do Itajaí, Itajaí, SC, Brazil.

Marôco, J. (2010). Análise de equações estruturais: Fundamentos teóricos, software \& aplicações. Lisbon: Report Number.

Marôco, J. (2011). Análise estatística com o SPSS statistics. Pêro Pinheiro: Report Number.

Marôco, J., \& Garcia-Marques, T. (2006). Qual a fiabilidade do alfa de Cronbach? Questões antigas e soluções modernas?. Laboratório de Psicologia, 4(1), 65-90.

Mathieu, J. E., \& Zajac, D. M. (1990). A review and meta-analysis of the antecedents, correlates, and consequences of organizational commitment. Psychological Bulletin, 108(2), 171-194.

McGee, G. W., \& Ford, R. C. (1987). Two (or more?) dimensions of organizational commitment: Reexamination of the affective and continuance commitment scales. Journal of Applied Psychology, 72(4), 638-641.

Medeiros, C. A. F. (2003). Comprometimento organizacional: Um estudo de suas relações com características organizacionais e desempenho nas empresas hoteleiras (Tese de doutorado). Universidade de São Paulo, São Paulo, SP, Brazil.

Medeiros, C. A. F., \& Albuquerque, L. G. D. (2005). Comprometimento organizacional: Um estudo de suas relações com características organizacionais e desempenho nas empresas hoteleiras. Revista Psicologia Organizações e Trabalho, 5(2), 35-64.

Medeiros, C. A. F., Albuquerque, L. G. D., Marques, G. M., \& Siqueira, M. (2005). Um estudo exploratório dos múltiplos componentes do comprometimento organizacional. REAd-Revista Eletrônica de Administração, 11(1), 1-16.

Medeiros, C. A. F., \& Enders, W. T. (1998). Validação do modelo de conceitualização de três componentes do comprometimento organizacional (Meyer e Allen, 1991). Revista de Administração Contemporânea, 2(3), 67-87. 
Medeiros, C. A. F., Enders, W. T., Sales, I. D. O., Oliveira, D. D., \& Monteiro, T. D. C. (1999). Três (ou quatro?) componentes do comprometimento organizacional. Anais do XXIII Encontro da Associação Nacional de Pós-Graduação e Pesquisas em Administração [EnANPAD], Foz do Iguaçu, PR, Brazil, 23.

Melo, F. L. N. B., Fernandes, L. T., Araújo, A. G., Silva, M. P., \& Santos, F. J. S. (2014). Validação da escala de bases de comprometimento organizacional na gestão pública: Um estudo de caso no Tribunal de Contas do Estado do Rio Grande do Norte. Anais do Encontro da Associação Nacional de Pós-Graduação e Pesquisas em Administração [EnANPAD], Rio de Janeiro, RJ, Brazil, 38.

Melo, M. A. D. S., Bezerra, J. C. B., Coleta, M. F. D., Puente-Palacios, K. E., Coleta, J. A. D., \& Bezerra, A. L. Q. (2014). Organizational commitment of health surveillance workers in municipalities of the state of Goiás, Brazil. Trabalho, Educação e Saúde, 12(3), 655-677.

Menetti, S. A. P. P. (2013). O comprometimento organizacional da geração Y no setor de conhecimento intensivo (Dissertação de mestrado). Universidade Municipal de São Caetano do Sul, São Caetano do Sul, SP, Brazil.

Menetti, S., Kubo, E., \& Oliva, E. (2015). A geração Y brasileira e o seu comprometimento organizacional em empresas de conhecimento intensivo. Revista de Gestão dos Países de Língua Portuguesa, 14(2), 2-13.

Menezes, I. G., Aguiar, C. V. N., \& Bastos, A. V. B. (2016). Comprometimento organizacional: Questões que cercam sua natureza e os seus limites conceituais. Psicologia em Revista, 22(3), 768-789.

Menezes, I. G., \& Bastos, A. V. B. (2009). Bases sociológicas, antropológicas e psicológicas do comprometimento organizacional. Psicologia em Revista, 15(3), 200-215.

Meyer, J. P. (2009). Commitment in a changing world of work. In Klein, H. J., Becker, T. E., \& Meyer, J. P. (Eds.), Commitment in organizations: Accumulated wisdom and new directions (pp. 37-68). Florence: Routledge/Taylor and Francis Group.

Meyer, J. P., \& Allen, N. J. (1991). A three-component conceptualization of organizational commitment. Human Resource Management Review, 1(1), 61-89.

Meyer, J. P., Stanley, D. J., Herscovitch, L., \& Topolnytsky, L. (2002). Affective, continuance, and normative commitment to the organization: A meta-analysis of antecedents, correlates, and consequences. Journal of Vocational Behavior, 61(1), 20-52.

Morrow, P. C. (2011). Managing organizational commitment: Insights from longitudinal research. Journal of Vocational Behavior, 79(1), 18-35.

Morrow, P. C., McElroy, J. C., \& Scheibe, K. P. (2012). Influencing organizational commitment through office redesign. Journal of Vocational Behavior, 81(1), 99-111.

Mowday, R. T., Porter, L. W., \& Steers, R. M. (1982). Employee - organization linkages: The psychology of commitment, absenteeism, and turnover. New York: Academic Press.

Mowday, R. T., Steers, R. M., \& Porter, L. W. (1979). The measurement of organizational commitment. Journal of Vocational Behavior, 14(2), 224-247.

Oliveira, M. T. S. (2013). Comprometimento organizacional de Meyer e Allen - Um estudo de exploração e validação para Angola (Dissertação de mestrado). Universidade de Lisboa, Lisbon, Portugal.

O’Reilly, C. A., \& Chatman, J. (1986). Organizational commitment and psychological attachment: The effects of compliance, identification, and internalization on prosocial behavior. Journal of Applied Psychology, 71(3), 492-499.

O’Reilly, C. A., III, \& Pfeffer, J. (2001). Talentos ocultos: Como as melhores empresas obtêm resultados extraordinários com pessoas comuns. Rio de Janeiro: Campus.

Osigweh, C. A. (1989). Concept fallibility in organizational science. Academy of Management Review, 14(4), 579-594.

Pasquali, L. (1997). Psicometria: teoria e aplicações. Brasília: Universidade de Brasília.

Pena, L. M. L. M. (2009). Comprometimento de enfermeiros: Estudo de caso de um hospital privado em Belo Horizonte (Dissertação de mestrado). Faculdade Novos Horizontes, Belo Horizonte, MG, Brazil.

Pinto, M. P. C. (2011). Comprometimento organizacional: um estudo de suas relações com desempenho na carreira (Dissertação de mestrado). Faculdade de Ciências Empresariais da Universidade FUMEC, Belo Horizonte, MG, Brazil.

Rodrigues, A. C. A., \& Bastos, A. V. B. (2010). Problemas conceituais e empíricos na pesquisa sobre comprometimento organizacional: uma análise crítica do modelo tridimensional de J. Meyer e N. Allen. Revista Psicologia: Organizações e Trabalho, 10(2), 129-144.

Sá, M. A. D \& Lemoine, C. (1998). O estilo de liderança como fator de comprometimento na empresa. Anais do XXII Encontro Nacional da Associação Nacional de Programas de Pós-Graduação em Administração, Foz do Iguaçu, PR, Brazil. 
BBR

16,4

333

Silva, E.E. (2009). Trabalhador comprometido X obediente: explorando os limites conceituais e empíricos entre os construtos (Dissertação de mestrado). Universidade Federal da Bahia - UFBA, Salvador, BA, Brazil.

Silva, R. A. (2012). Bases do comprometimento da geração Y em uma empresa pública: Um estudo de caso (Tese de doutorado). Pontifícia Universidade Católica do Rio de Janeiro, Rio de Janeiro, RJ, Brazil.

Sousa, J. S., \& Honório, L. C. (2011). Comprometimento organizacional: Avaliando professores universitários em regimes diferenciados de carga horária de trabalho. Anais do XXXV Encontro da Associação Nacional de Pós-Graduação e Pesquisas em Administração [EnANPAD], Rio de Janeiro, RJ, Brazil, 1-16.

Ullman, J. B. (2007). Structural Equation Modeling. In Tabachnick, B. G. \& Fidell, L. S. (Eds.), Using multivariate statistics (5th ed.). Boston: Pearson.

Wiener, Y. (1982). Commitment in organizations: A normative view. Academy of Management Review, 7(3), 418-428.

Worthington, R. L., \& Whittaker, T. A. (2006). Scale development research: A content analysis and recommendations for best practices. The Counseling Psychologist, 34(6), 806-838.

The authors declare that there is no conflict of interest. The first two authors were responsible for the execution of all stages of the work, while the third author collaborated in the orientation and methodological review and the fourth in the general revision of the article and theoretical orientation. 